\title{
NDRG1 wt Allele
}

National Cancer Institute

\section{Source}

National Cancer Institute. NDRG1 wt Allele. NCI Thesaurus. Code C52086.

Human NDRG1 wild-type allele is located in the vicinity of $8 q 24.3$ and is approximately 60 $\mathrm{kb}$ in length. This allele, which encodes protein NDRG1, is involved in regulation of both cell differentiation and cell growth. Certain allelic variants of the NDRG1 gene cause Charcot-Marie-T ooth disease type 4D. Expression of the NDRG1 gene is up-regulated in several types of cancer such as breast cancer, colorectal carcinoma and prostate cancer. 